\title{
Pengaruh Emotional Intelligence Dan Attitude Terhadap Entrepreneurial Intention Pada Mahasiswa Falkultas Hukum Universitas Tarumanagara
}

\author{
Djoko Sugiarto dan Oey Hannes Widjaja \\ Program Studi Manajemen Fakultas Ekonomi \\ Universitas Tarumanagara, Jakarta \\ Email: jokosugiarto9@gmail.com
}

\begin{abstract}
The purpose of this study was to determine whether there was a significant influence between the variables of Emotional Intelligence and Attitudes towards Entrepreneurship Intentions at the Law Faculty Students at Tarumanagara University. The research manipulation is the Law Faculty Tarumanagara University Students. The sampling method used was non-probability sampling technique. The data collection method was carried out using the questionnaire method and then given to 200 respondents. All data analysis techniques use the IBM SPSS Statistics 25 program. The results of this study indicate that all data have passed the assumption requirements. Based on the partial $t$ test, it shows the hypothesis that the variable Emotional Intelligence and Attitude has a significant influence on Entrepreneurship Intention for Law Faculty Tarumanagara University Students.
\end{abstract}

Keyword: Emotional Intelligence, Attitude, Entrepreneurial Intention.

\begin{abstract}
Abstrak: Tujuan penelitian ini adalah untuk mengetahui apakah ada pengaruh yang signifikan antara variabel Kecerdasan Emosional dan Sikap terhadap Niat Kewirausahaan pada Mahasiswa Falkultas Hukum Universitas Tarumanagara. Pepulasi penelitian ini adalah Mahasiswa Falkultas Hukum Universitas Tarumanagara. Metode pengambilan sampel yang dilakukan dengan teknik non-probability sampling. Metode dengan pengumpulan data dilakukan dengan metode kuisioner lalu di berikan keada 200 reponden. Semua teknik analisis data menggunakan program IBM SPSS Statistic 25. Hasil penelitian ini menunjukan bahwa semua data telah lolos dari persyaratan asumsi. Berdasarkan uji t parsial , menunjukan hiotesis bahwa variabel Kecerdasan Emosional dan Sikap memiliki pengaruh signifikan terhadap Niat Kewirausahaan untuk Mahasiswa Falkultas Hukum Universitas Tarumanagara.
\end{abstract}

Kata Kunci: Kecerdasan Emosional, Sikap, Niat Kewirausahaan. 


\section{LATAR BELAKANG}

Berwirausaha merupakan salah satu cara untuk meningkatkan perekonomian di suatu negara. Suatu negara akan sejahtera jika persentase wirausahawannya paling sedikit $2 \%$ dari total penduduknya. Wirausahawan di Indonesia masih dianggap minim sehingga Indonesia membutuhkan para wirausahawan muda sebagai pemicu utama untuk meningkatkan perekonomian di negara Indonesia. Namun pada kenyataannya para penduduk usia muda, termasuk para mahasiswa yang memiliki potensi paling tinggi menjadi calon wirausaha muda, belum tentu memiliki keinginan untuk memulai suatu usaha, sehingga dibutuhkan sesuatu yang mampu mendorong minat berwirausaha seseorang, seperti kecerdasan emosional dan sikap.

Keberhasilan hidup seseorang pada dasarnya tergantung pada kecerdasan yang dimiliki. Kecerdasan tersebut terdiri dari kecerdasan emosional, kecerdasan intelektual, dan kecerdasan spiritual. Dalam mencapai keberhasilan tentu banyak hambatan-hambatan yang harus dilewati, sehingga kecerdasan yang dimiliki tersebut dapat dioptimalkan. Namun manusia bukanlah makhluk sempurna, seseorang yang cerdas secara intelektual belum tentu cerdas secara emosi dan spiritual. Pada dasarnya kecerdasan emosi dapat membantu seseorang untuk mengatasi hambatan-hambatan yang ada dalam keberhasilannya. Individu yang memiliki kecerdasan otak atau memiliki gelar tinggi belum tentu sukses berkiprah di dunia pekerjaan. Bahkan sering kali seseorang yang berpendidikan formal lebih rendah malah lebih sering berhasil.

Menurut Purwohandoko (2015) dimana terdapat sikap yang mendukung seorang wirausaha supaya mencapai keberhasilan dalam usahanya seperti mempunyai motivasi berprestasi tinggi, Menurut Suryana (2009) sebuah proses sikap kreatif dan inovatif hanya mampu di lakukan oleh orang yang mempunyai jiwa, sikap dan perilaku kewirausahaan dengan ciri percaya diri tinggi, Memiliki inisiatif, berprestasi, Berani dalam mengambil sebuah resiko dengan penuh hitungan.

Menurut Suryana (2009) proses dalam kewirausahaan di awali oleh suatu paham, yaitu terdapat tantangan. Oleh tantangan tersebut timbullah suatu gagasan serta kemauan dan sebuah dorongan dalam berinisiatif, yang tidak lain ialah berfikir inovatif dan bertindak kreatif, sehingga tantangan awal tadi teratasi dan terpecahkan. Dimana setiap tantangan memang memiliki resiko, tapi ketika individu itu mampu mengatasinya dengan baik maka tantangan tersebut akan menjadi kesempatan untuknya. Maka dari itu, penulis ingin meneliti Emotional Inttelegence, Attitude, Entrepreneurial Intention seberapa berpengaruhnya terhadap Mahasiswa Falkultas Hukum di Universitas Tarumanagara.

Adapun Tujuan penelitian dalam penelitian ini adalah untuk mengetahui apakah:

a. Untuk mengetahui apakah Emotional Intelligence memiliki pengaruh secara signifikan terhadap Entrepreneurial Intention pada Mahasiswa Falkultas Hukum di Universitas Tarumanagara.

b. Untuk mengetahui apakah Attitude memiliki pengaruh secara signifikan terhadap Entrepreneurial Intention pada Mahasiswa Falkultas Hukum di Universitas Tarumanagara. 


\section{KAJIAN TEORI}

Ashkanasy dan Daus, (2005). mengkategorikan tindakan EI menjadi tiga jenis: kemampuan EI, laporan mandiri EI berdasarkan model empat-cabang EI, dan tindakan EI campuran. Kemampuan langkah-langkah EI didasarkan pada konsep bahwa EI adalah jenis kecerdasan, dan dengan demikian harus diukur dengan item yang benar dan salah objektif seperti cara kecerdasan lainnya biasanya diukur.

Crant, J.M., (1996). menggambarkan sikap kewirausahaan sebagai sikap yang berhubungan dengan keinginan seorang individu untuk memiliki bisnis. Ini bisa menjadi sikap terhadap perusahaan yang memotivasi niat individu untuk terlibat dalam usaha baru.

Fishbein \& Ajzen, (1975). niat kewirausahaan adalah tingkat keseriusan dorongan untuk berperilaku dengan cara tertentu. Niat untuk menjadi seorang pengusaha menjelaskan seberapa jauh seseorang memiliki dorongan atau termotivasi untuk memiliki perilaku kewirausahaan. Jika dorongan kuat, orang tersebut dikatakan memiliki niat yang kuat dan sebaliknya. Peran niat sangat penting, karena akan menentukan nilai dan hasil yang akan didapat sebagai konsekuensi dari perilaku yang dipilih.

Emotional Intelligence (X1). Menurut (Goleman, 2002), kecerdasan emosional adalah kemampuan seseorang mengatur kehidupan emosinya dengan inteligensi (to manage our emotional life with intelligence); menjaga keselarasan emosi dan pengungkapannya (the appropriateness of emotion and its expression) melalui keterampilan kesadaran diri, pengendalian diri, motivasi diri, empati dan keterampilan sosial.

Attitude (X2). Menurut (Wu dan chen, 2014) menunjukkan bahwa sikap dipengaruhi oleh keyakinan perilaku. Dengan demikian, sikap didasarkan pada kepercayaan dan atribut tentang suatu objek yang mempengaruhi individu untuk berperilaku secara konsisten menurut mereka.

Entrepreneurial Intention (Y). Menurut (Ridha dan wahyu, 2017) : Thompson, (2009) Niat (Entrepreneurial Intention) dapat didefinisikan sebagai "keyakinan yang diakui sendiri" oleh setiap individu bahwa ia bersedia untuk memulai perusahaan bisnis baru, dan ia terus berencana untuk mencapai ini di masa depan.

Kaitan antara Emotional Intelligence terhadap Entrepreneurial Intention. Menurut Zampetakis dkk. (2008), seseorang lebih mungkin untuk merumuskan minat untuk memulai bisnis mereka sendiri, ketika mereka memiliki sifat efikasi diri yang tinggi, yaitu keyakinan bahwa sukses bisa merasa, mengenali, mengatur, mengendalikan, dan mengevaluasi emosi mereka sendiri dan orang lain.

Berdasarkan uraian diatas maka dapat diambil hipotesis sebagai berikut:

H1 : Terdapat pengaruh yang positif dan siginifikan Emotional Intelligence terhadap Entrepreneurial Intention.

Kaitan antara Attitude Terhadap Entrepreneurial Intention. Menurut (Franke dan Luthje, 2004) menemukan hubungan positif yang kuat antara sikap terhadap wirausaha dan 
niat untuk menjadi wirausaha. Dalam sebuah survei terhadap mahasiswa disiplin ilmu teknik di Massachusetts Institute of Technology.

Berdasarkan uraian diatas, maka dapat diambil hipotesis sebagai berikut:

H2 : Terdapat pengaruh yang positif dan signifikan Sikap terhadap Niat Kewirausahaan.

Berdasarkan uraian tersebut maka terbentuk kerangka pemikiran dan hipotesis. Model kerangka pemikiran dan hipotesis diuraikan sebagai berikut :

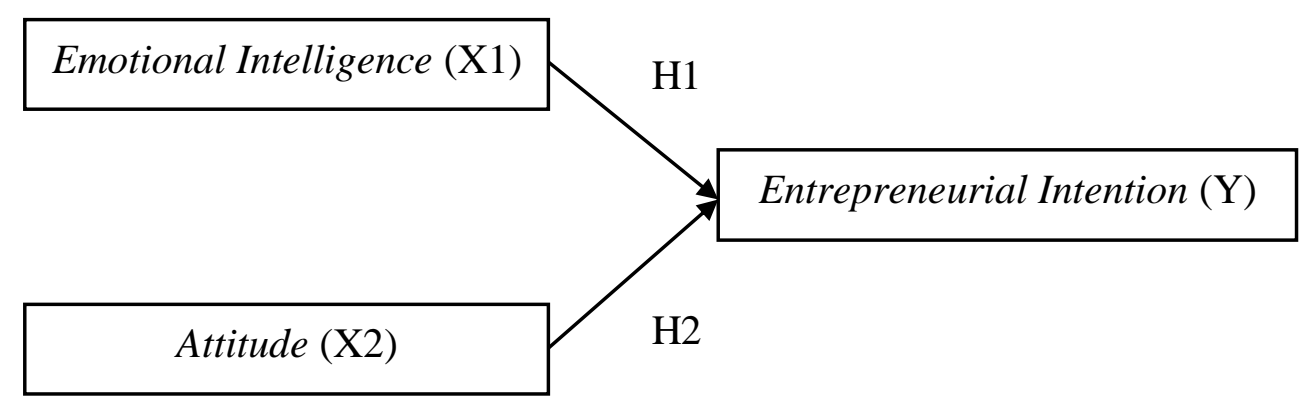

\section{METEDOLOGI}

Dalam penelitian ini, desain penelitian yang digunakan adalah desain penelitian merupakan suatu panduan untuk mengumpulkan dan mengolah analisis data untuk mengerjakan suatu kerangka atau merencanakan suatu penelitian. Di dalam penelitian ini, desain penelitian yang digunakan adalah desain penelitian deskriptif dengan crosssectional.

Populasi penelitian ini adalah Mahasiswa Falkultas Hukum Universitas Tarumanagara. Sedangkan jumlah yang akan di teliti adalah sebanyak 200 Responden Mahasiswa. Metode pemilihan sampel yang digunakan pada penelitian ini adalah metode pemilihan sampel secara bukan acak atau non-probability sampling dengan teknik pemilihan sampel yaitu Judgemental Sampling.

Pengukuran variabel-variabel dalam penelitian ini mengacu pada penelitian sebelumnya antara lain sebagai berikut:

Variabel

Emotional Intelligence

Attitude

Entrepreneurial Intention
Indikator

5 item

5 item

3 item

\section{Acuan}

Hassan, Ramraini Ali; Omar, Siti Norashikin Binti (2016) Hassan, Ramraini Ali; Omar, Siti Norashikin Binti (2016) Hassan, Ramraini Ali; Omar, Siti Norashikin Binti (2016)

\section{Hasil Uji Statistik}

Berdasarkan data subjek penelitian yang berjumlah 200 reponden diperoleh dengan Gender laki-laki sebanyak 55,5\% dan perempuan sebanyak 44,5\%. Berdasarkan Usia 17 Tahun sebanyak 1\%, Usia 17-19 Tahun sebanyak 29,5\%, Usia 20-22 Tahun sebanyak $57 \%$, Usia > 22 Tahun sebanyak 12,5\%. Dari segi Domisili, yang berdomisili di DKI 
jakarta sebanyak $71 \%$, Tangerang sebanyak 18\%, Bogor sebanyak 6\%, Depok sebanyak $5 \%$. Selain iu reponden merupakan mahasiswa Falkultas Hukum Universitas

Tarumanagara.

\section{Analisis Regresi Berganda}

Tabel 1. Hasil Analisis Regresi Berganda

\begin{tabular}{|c|c|c|c|c|c|c|}
\hline & & $\begin{array}{r}\text { Unst } \\
\text { Co }\end{array}$ & $\begin{array}{l}\text { Indardized } \\
\text { efficients }\end{array}$ & $\begin{array}{c}\text { Standardized } \\
\text { Coefficients }\end{array}$ & & \\
\hline & Model & B & Std. Error & Beta & $\mathbf{t}$ & Sig. \\
\hline 1 & (Constant) & .769 & 1.316 & & .584 & .560 \\
\hline & Emotional Intelligence & .156 & .077 & .173 & 2.033 & .043 \\
\hline & Attitude & .394 & .083 & .402 & 4.724 & .000 \\
\hline
\end{tabular}

Sumber: hasil pengolahan data kuesioner dengan menggunakan SPSS 25.00

Berdasarkan Tabel 1, di atas, maka persamaan regresi linear bergandanya adalah sebagai berikut: $\mathrm{Y}=0.769+0.156 \mathrm{X}_{1}+0.394 \mathrm{X}_{2}$

\section{Koefisien Determinasi}

Tabel 2. Hasil Analisis Koefisien Determinasi

\begin{tabular}{|c|c|c|c|c|}
\hline Model & $\mathbf{R}$ & R Square & Adjusted R Square & $\begin{array}{c}\text { Std. Error of the } \\
\text { Estimate }\end{array}$ \\
\hline 1 & $.539^{\mathrm{a}}$ & .291 & .284 & 1.755 \\
\hline
\end{tabular}

Sumber: hasil pengolahan data kuesioner dengan menggunakan SPSS 25.00

Berdasarkan Tabel 2, Nilai Koefisien determinasi ganda (R2) Tabel 2 sebesar 0.284 atau sebesar 28,4\% artinya proporsi variasi variabel Y (Entrepreneurial Intention) yang dapat di jelaskan oleh variabel X1 (Emotional Intelligence) dan variabel X2 (Attitude) sebanyak $28,4 \%$ sisanya $71,6 \%$ dapat dijelaskan dari variabel lain.

\section{Pengujian Hipotesis}


Tabel 3. Hasil Analisis Uji F

\begin{tabular}{|l|l|r|r|r|r|r|}
\hline \multicolumn{2}{|l|}{ Model } & Sum of Squares & df & Mean Square & F & Sig. \\
\hline \multirow{3}{*}{1} & Regression & 249.013 & 2 & 124.506 & 40.430 & $.000^{\mathrm{b}}$ \\
\cline { 2 - 7 } & Residual & 606.667 & 197 & 3.080 & & \\
\cline { 2 - 7 } & Total & 855.680 & 199 & & & \\
\hline
\end{tabular}

Sumber: hasil pengolahan data kuesioner dengan menggunakan SPSS 25.00

Berdasarkan Tabel 3, besarnya nilai $\mathrm{F}$ hitung yaitu sebesar 40.430 dan nilai signifikannya yaitu sebesar 0.000 . karena nilai signifikannya 0.000 lebih kecil dari atau < 0.05 maka dapat disimpulkan bahwa Emotional Intelligence dan Attitude memiliki pengaruh signifikan terhadap Entrepreneurial Intention.

Tabel 4. Hasil Analisis Uji t

\begin{tabular}{|c|c|c|c|c|c|c|}
\hline \multicolumn{7}{|c|}{ Coefficients $^{\mathrm{a}}$} \\
\hline \multirow{2}{*}{\multicolumn{2}{|c|}{ Model }} & \multicolumn{2}{|c|}{$\begin{array}{c}\text { Unstandardized } \\
\text { Coefficients }\end{array}$} & \multirow{3}{*}{\begin{tabular}{|c|} 
Standardized \\
Coefficients
\end{tabular}} & \multirow[b]{2}{*}{$\mathrm{t}$} & \multirow{3}{*}{$\begin{array}{l}\text { Sig. } \\
.560\end{array}$} \\
\hline & & B & Std. Error & & & \\
\hline \multirow[t]{3}{*}{1} & (Constant) & .769 & 1.316 & & .584 & \\
\hline & $\begin{array}{l}\text { Emotional } \\
\text { Intelligence }\end{array}$ & .156 & .077 & .173 & 2.033 & .043 \\
\hline & Attitude & .394 & .083 & .402 & 4.724 & .000 \\
\hline
\end{tabular}

a. Dependent Variable: Entrepreneurial Intention

Sumber: hasil pengolahan data kuesioner dengan menggunakan SPSS 25.00

Berdasarkan Tabel 4, di atas hasil Uji t dapat diketahui besarnya $\mathrm{t}$ hitung dan nilai signifikasi masing-masing Variabel Independen.

Emotional intelligence $\left(X_{1}\right)$ memiliki nilai signifikasi 0.043 yang berarti lebih kecil dari atau $<0.05$. Oleh karena itu dapat disimpulkan bahwa $H_{1}$ dalam penelitian ini yang telah di rumuskan sebelumnya yang menyatakan bahwa 'Emotional Intelligence memiliki pengaruh signifikan terhadap Entrepreneurial Intention" di Terima, karena Emotional Intelligence memiliki angka yang positif dan juga signifikan yaitu sebesar 0.043.

Selanjutnya Attitude $\left(X_{2}\right)$ memiliki nilai signifikasi 0.000 yang berarti lebih keci dari $<0.05$. Oleh karena itu dapa disimpulkan bahwa $H_{2}$ dalam penelitian ini telah di rumuskan sebelumnya yang menyataka bahwa "Attitude memiliki pengaruh signifikan terhadap Entrepreneurial Intention" di Terima, karena Attitude memiliki angka yang positif dan juga Signifikan yaitu sebesar 0.000 . 


\section{DISKUSI}

Pada hasil pengujian hipotesis $\left(\mathrm{H}_{1}\right)$ menunjukan bahwa Emotional Intelligence memiliki hubungan positif terhadap Entrepreneurial Intention pada Mahasiswa Falkultas Hukum Universitas Tarumanagara, sehingga disimpulkan bahwa $\left(\mathrm{H}_{1}\right)$ Diterima. Hasil penelitian sesuai dengan Miao, Chao; Humphrey, Ronald H; Qian, Shanshan; Pollack, Jeffrey M. Career Development International, (2018) yang menyatakan bahwa hasil metaanalisis ini menunjukkan bahwa Emotional Intelligence berhubungan positif dengan Entrepreneurial Intention;

Selanjutnya berdasarkan hasil pengujian hipotesis $\left(\mathrm{H}_{2}\right)$ menunjukan bahwa Attitude memiliki hubungan positif terhadap Entrepreneurial Intention pada Mahasiswa Falkultas Hukum Universitas Tarumanagara, sehungga disimpulkan bahwa $\left(\mathrm{H}_{1}\right)$ Diterima. Hasil penelitian sesuai dengan Schwarz, E. , Wdowiak, M. , Almer-Jarz, D. dan Breitenecker, R. (2009) yang menyatakan bahwa hasil Attitude berpengaruh signifikan terhadap entrepreneurial Intention

\section{PENUTUP}

Berdasarkan hasil pengujian data dalam penelitian ini, menghasilkan dua jawaban, (1) yaitu terdapat pengaruh positif dan signifikan Emotional Intelligence terhadap terhadap Entrepreneurial Intention. (2) yaitu terdapat pengaruh positif dan signifikan Attitude terhadap Entrepreneurial Intention.

Pada penelitian ini terdapat beberapa keterbatasan : (1) Penulis hanya menggunakan sebanyak 200 reponden. (2) penelitian ini hanya melakukan penelitian ini dilingkup Mahasiswa Falkultas Hukum Universitas Tarumanagara. (3) penelitian ini hanya dibatasi dengan menggunakan Variabel Emotional Intelligence, Attitude, dan Entrepreneurial Intention

Peneliti menyarankan untuk kepada Mahasiswa Falkultas Hukum Universitas Tarumanagara :

(1) Untuk menjadi pembisnis maupun wirausahawan perlunya Emotional Intelligence dimana semakin baik Emotional Intelligence seorang wirausaha/pembisnis maka semakin baik juga pola pikir seseorang dalam mengatur emosi dan mampu meningkatkan kemampuan dalam pikiran. (2) Untuk menjadi pembisnis maupun wirausahawan perlunya Attitude yang mencerminkan rasa senang dalam berwirausaha, tingkah laku yang baik terhadap siapapun.

\section{DAFTAR PUSTAKA}

Ashkanasy, N. M., \& Daus, C. S. (2005). Rumors of the death of emotional intelligence in organizational behavior are vastly exaggerated. Journal of Organizational Behavior, 26: 441-452.

Crant, J.M., (1996), Skala Kepribadian Proaktif sebagai Prediktor Niat Kewirausahaan. Jurnal Manajemen Usaha Kecil, Vol 34

Fishbein, M., \& Ajzen, I. (1975). Belief, attitude, intention, and behavior: An introduction to theory and research. Reading, MA: Addison-Wesley. 
Franke, N. and Lüthje, C. (2004), "Entrepreneurial intentions of business students: a benchmarking study", International Journal of Innovation and Technology Management, Vol. 1 No. 3, pp. 269-88.

Goleman, D. (2002). Emotional Intelligence: Kecerdasan Emosional (mengapa EQ lebih penting daripada IQ). Jakarta: PT. Gramedia Pustaka Utama.

Hassan, Ramraini Ali; Omar, Siti Norashikin Binti. (2016). "The Effect of Emotional Intelligence and Entrepreneurial Attitude on Entrepreneurial Intention". Scholarly Journals, Vol 5 No 12, pp. 1-10

Purwohandoko. (2015). Kewirausahaan. Surabaya: Unesa University Press

Ridha, R.N. and Wahyu, B.P. (2017), "Entrepreneurship intention in agricultural sector of young generation in Indonesia", Asia Pacific Journal of Innovation and Entrepreneurship, Vol. 11 No. 1, pp. 76-89

Suryana. (2009). Kewirausahaan. Jakarta: Salemba Empat

Wu, S.I., \& Chen, J.Y. (2014). A model of green consumption behavior constructed by the theory of planned behavior. International Journal of Marketing Studies, 6, 119-132.

Zampetakis, L., Kafetsios, K., Bouranta, N., Dewett, T. and Moustakis, V.(2008), "On the relationship between emotional intelligence and entrepreneurial attitudes and intentions", International Journal of Entrepreneurial Behavior \& Research, Vol. 15 No. 6, pp. 595-618. 